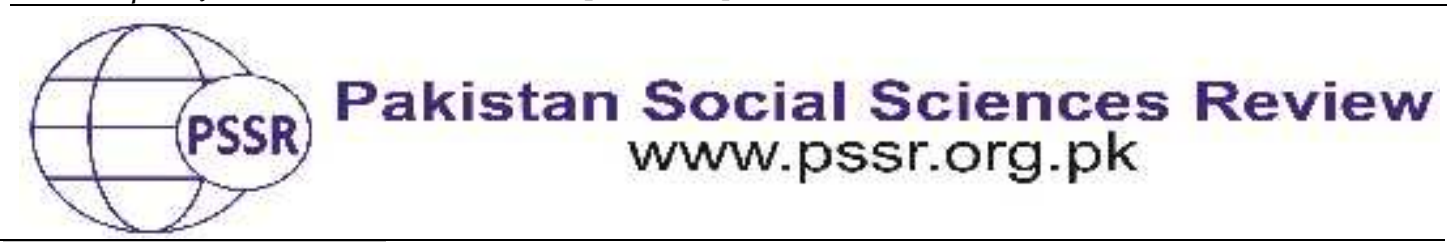

RESEARCH PAPER

\title{
Economic Empowerment of Women through Entrepreneurial Education in Pakistan: Issues and Challenges
}

\author{
Saira Maqbool ${ }^{* 1}$ Dr. Qaisara Parveen ${ }^{2}$ Dr. Muhammad Imran Yousuf ${ }^{3}$
}

1. Ph. D Scholar, Department of Education, Faculty of Social Sciences, Pir Mehr Ali Shah Arid Agriculture University Rawalpindi, Pakistan

2. Assistant Professor, Department of Education, Faculty of Social Sciences, Pir Mehr Ali Shah Arid Agriculture University Rawalpindi, Pakistan.

3. Associate Professor/Chairman, Department of Education, Faculty of Social Sciences, Pir Mehr Ali Shah Arid Agriculture University Rawalpindi, Pakistan.

\section{PAPER INFO}

Received:

March 29, 2021

Accepted:

May 01, 2021

Online:

May 15, 2021

Keywords:

Empowerment,

Entrepreneurship

Education,

Female Development

*Corresponding

Author

saira.maqbool 81

@gmail.com

\section{ABSTRACT}

The growing passion for Entrepreneurship in Pakistan is viewed as feasible answer for unemployment. In Pakistan Females are engaged through trade innovativeness, which has turned into an essential piece of our expansion actions as a result of three critical grounds, Female's enlargement, monetary growth and Common safety. The objective of this analysis is to find out the challenges which were being faced by students when they started their new ventures. The results determine that the association between Entrepreneurial education and skillful improvement of females are very strong. The Qualitative information was examined through content analysis. In Entrepreneurial instruction a substantial portion of positive change can be proposed like upgraded mindfulness in regard to an assortment of social, money related, specialized, professional and preparing issues with the assistance of appropriate directing venture. After analysis it is assumed that basic Entrepreneurial Training is very important for empowerment of female students.

\section{Introduction}

Expansion of Women Entrepreneurship is measured as a serious commitment to development in Pakistan. Thus, the Female in Pakistan instigated to take part in business ventures, although the participation rate in these entrepreneurial activities is not very high, but women are struggling. They are facing many problems financial, social, from other gender but they are doing consistently. One of the key factors in deciding the realization of enhancement is the status and position of females in the general public (Akhtar et al., 2021). This implies that neglecting towards Female in the development procedure of any nation comprises a human resource to be wasted. So, this study focuses on that point that there is deep relationship between Entrepreneurship Education and Women Empowerment. 
Women empowerment is the key to success for any nation. Women are the better half of the society and need equal opportunity of excess in all disciplines of higher education in Pakistan (Naseer-ud-din et al., 2010). In Pakistan now a day's many public and private organizations are giving Entrepreneurial trainings, many women are associated with these organizations or institutes in which TEVETA (Technical Education and Vocational Training Authority Punjab) Skill Development Council Punjab ,Islamabad and Rawalpindi Chamber of Commerce, NIC (National Incubation Centre) in whole country, Technical and Vocational institutes in Pakistan, LUMS (Lahore University of Management Sciences, National Vocational \& Technical Training Commission (NAVTTC), Pakistan Authority, MDI (Management Development Institute) Women X (The Women X program is a World Bank worldwide creativity to encourage the spirit of women entrepreneurs in developing countries.),WE CREATE centers are serving an entrepreneurial communal center for women who are interested in starting or increasing a present business, WECON (Women Entrepreneurship Conferences) are giving trainings to Women Entrepreneurs. WECON Movement is considered as a platform for empowering the women of Pakistan by connecting them with entrepreneurial awareness opportunities and giving them access to better.

Though this concept is new but lack of awareness in this field makes problems for Pakistani women. UNDP (2005) centers around gender orientation uniformity and females' strengthening as common freedoms, yet in addition since they are a pathway to accomplishing the Millennium Development Goals and maintainable advancement now a days many women and students peruse their small-scale business beside with their jobs and education, some women only work on their ventures because from home they can be empowered through their home business after generating revenues. If they get proper training that can be more helpful for their ventures. Vocational and Entrepreneurial educational training can improve the hidden abilities for entrepreneurship.

\section{Literature Review}

"When you empower a man, you empower an individual; when you empower a woman, you empower a nation." HE Tebelelo Seretse, Ambassador of Botswana to the United States.

Women Empowerment can be said as a technique in which Females encountered with the present principles and culture, to usefully develop their individuality, position in the family and also in the general public. Good system of education tries to empower unique abilities among female students to recognize their own capabilities (Yousuf \& Imran, 2018).Entrepreneurship on little scale makes women enable particularly who cannot determine the professions for some such causes. In urban zone, women from lower level of the general public however they are well educated but find difficulty to get the jobs. Self-helping teams in this means help them through Entrepreneurship. 
The substantial effect of Entrepreneurship did not raise their financial status however as well as it gives females their own identity and social position. Female Entrepreneur is a person who recognizes testing job and in addition they meet with their own needs and turn out to be financially independent. A strong involvement to complete something positive is an inbuilt nature of Entrepreneurs, to contribute values in both personal and public activity. With the advancement of media and especially social media, women get more awareness regarding their own qualities and working conditions. This is the digital period and many women are job providers instead of job seeker. Many women are ready to start their own ventures; they come as designers, Beauticians, caterers, Event organizers, decorators and exploring new avenues of monetary involvement. Women from all fragments from Pakistani economy cannot be remote from the structure of economic development. The role of women gradually increases as successful Entrepreneurs. The central device of women empowerment is the women entrepreneurship development through Entrepreneurship Education. The women who are empowered they fulfilled their desires and live better life with selfrespect (Rubab et al., 2021). They are more confident and successful. Entrepreneurship makes the women empowered and increases the economy of country.

Entrepreneurship education looks to give understudies the learning, abilities and motivation to empower themselves in variety of settings. Diversities of Entrepreneurship instruction are offered at all stages of students from school to colleges. Entrepreneurship teaching centers around the enhancement of capabilities or individualities that empower the students on their own desires.

Converting an idea into action had been prepared since the establishment of cultivation round the world. It has truly converted the world. Businesspersons had been forming endeavors which based on such notions and materialized them into suitable activities. Entrepreneurs had a dream for doing things in an improved way, they think beyond the restrictions of existing rules and capitals (Nachimuthu\& Gunatharan, 2012). Perhaps more important that, they have the craving and insistence of doing something, which require them to take risks so that they realize their idea. Thus, entrepreneurship is not just a project construction method; its soul serves as a representative of change. It is common and is replicated in all major scopes of evolution viz. social, political, and economic etc. across the world (Betancourt et al., 2011).

Gartner \& Shane (1995) believes that the twentieth century remained the era of incredible advancement for Entrepreneurship. It is most usually assumed as business ventures however it can be related with all dimensions of life including society, nation and patterns in mechanical headways (Kuratko, 2005).

Kuratko (2005) basically describes that it as an active practice of vision, transformation, and creation. Kuratko and Hodgetts (2013) focused on the point that Entrepreneurship involves individual capabilities that combine the readiness to meet exposure, hesitation, and dangers regarding time, cash and job; the personal skill of building teams in a business adventure; innovative skills of figuring strong marketable approaches and arranging all the required assets and furthermore the interesting 
visualization for recognizing the open door where others see mayhem, logical irregularity, and confusion Entrepreneurship has been seen from three wide viewpoints (Ward, 2006): From Economic perception: it considers the Entrepreneur to play the role in the economic expansion of a people, country or region. From Sociological perception: it considers that the entrepreneurs as participants of a social system and who are prejudiced by and, through their entrepreneurial actions inspired the social atmosphere and the behavior qualities that the sociological system motivates (Kumar\& Kumar, 2015). From Idiosyncratic perception: its emphases on that the entrepreneur as an individual with a distinctive arrangement of personal individualities and opinions.

\section{Empowerment}

Empowerment can be categorized as a practice of completing all the more controlling capability to provoke the query on existing force and to authority over the source of strength (Batliwala, 1994). Empowerment is at the same time a method and that aftereffect of the technique. The way toward testing prevailing force associations and of growing more noteworthy power over the wellsprings of intensity might be named as Empowerment restructures control from the extreme to the frail. Parsad \& Sahey (2000) argued it is more than assistance in basics of leadership; it should likewise integrate the technique that leads persons to see themselves as skillful and trained for decide.

Instrument of Female Empowerment is independent work or Entrepreneurship. Why females get the option for independent work or Entrepreneurship? One investigation revealed that self-sufficiency was assessed as high as a way to attain individual opportunity. This level of freedom gives the chances to: Able to make their very own selections: - basic leadership of females shows that decision making which is the foundation of Empowerment. Empowerment makes the women able to do finest work-work in non-customary fields recommends opening to all the more dominant linkage, which drives specifically to the Empowerment. And achieve financial liberation which is a noteworthy donating element in the establishment of females (Gopika et al., 2015).

A status report deliver specifics regarding females' financial importance and establishment in Pakistan was boosted at an event together assisted by the National Commission on the Status of Women (NCSW) and the United Nations Unit for Gender Equivalence and the Empowerment of Women (UN Women).'Women's Financial Involvement and Empowerment - Status Report 2016' highlights the changeable and complicated indication of females' fiscal establishment and in developing the domestic summary information and individual inquiries which archives the prestige of Pakistani females to several dimensions and elements of fiscal involvement. The report features the precise parts of females' economic firming and suggests a decisive action to increase females' appearance, lead-ins and dimensions with the end goal for women to take interest as full regulatory performing artists in the enhancement and expansion of a vigorous Pakistan that the Idea 2025 pursues. Foremost Focal point of gender orientation and Attitude Trainings and Central Expert and Originator for the Status Report 2016 Dr Yasmin Zaidi in presenting the report featured: "Females' economic 
work, paid and unpaid, should be professed, renowned and monitored at the area and commonplace levels in Pakistan with the aim that Pakistan can inspect SDG 5" (Sustainable development goals).

\section{The Economic Role of Women in Pakistan}

Females establish half of the Pakistan's 190 million population and declare as a main piece of the work force. Unlike the past, females assume a serious job helping Pakistan with excitement and obligation by their abundant pledges as designers, experts, critics, navigators, professors and social employees (Muhib\& Khan, 2010). Women participation at grass root level can boost up the overall process of socioeconomic development of Pakistan (Ranjha et al., 2011). However, they want more chances to adopt a more noticeable job in the pecuniary enlargement of the country. Female employment rate in Pakistan is the maximum condensed on the planet (4.3 percent) and it is appraised that rural ladies put in 14 to 16 hours in cultivating and farming. In 2003-2004, the enlargement rate of females' collaboration was 15.9 percent. The number extended somewhat to 18.9 percent the next year which is slight contrasted with whatever remains of South Asia (Najeeb et al., 2020).

Nearly 65 percent of female Doctors do not work after marriage, 80 percent of business graduates sit at home after marriage, and fewer than 10 percent of educated females are Entrepreneurs. Pakistani females' professions are normally constrained to instructing, client care, call centers, scheduling, preparing and fashion. In context of developing as an economically liberated country, a comprehensive arrangement must be trailed to exclude gender inequality. We all know that, and it is all around accepted that no country can be operative without the help and support of their female population in different arenas, for example, preparation, human services, little and standard trade, supplies, saving money, fashion, electronic and print media(Mohsin \& Syed, 2020).

\section{Material and Method}

\section{Research Design}

The goal of this study was to know the challenges and problems faced by female students when they started their ventures, their perceptions about women empowerment and Entrepreneurial Education, finding the linkage between women Empowerment and Entrepreneurship Education, to identify the significance of Entrepreneurial Education on Women Empowerment or to recommend some feasible answers for empowering; generating; and improving the Women Empowerment in rising economies.

The inhabitants were female students from undergraduate level of Pir Mehr Ali Shah Arid Agriculture University Rawalpindi who are currently started their ventures and earning revenue. First step was the identification of three cases of success stories from enrolled undergraduate students of targeted university. For this purpose three 
Entrepreneurs were identified through snow ball sampling. Criteria for selection was that student should be enrolled at undergraduate level, engaged in entrepreneurial venturing and have started earning.

After analyzing the literature review related to matter instrument was developed. Interview guide was selected as instrument. Data was assembled from students from PMAS-Arid Agriculture University and administered personally. Combining the data in that way to order so it can easily answer the research question, an appropriate research technique is needed to be create the researcher choice is for structured interviews and how they have been conducted was described. In case of qualitative research, several ways can be applied, such as interviews, ethnographic studies or focus groups discussions. For this purpose, interviews look like to be an appropriate technique because they are allowed or enquiring open ended questions and discovering specific practices or views regarding the required spectacle.

Information was broken down by coding the responses of students. Every response was decoded by the researchers and discussed in findings and conclusion section. After conduction of interview process responses were recorded in order to manner them for the later analysis. A proper method for this purpose seems to be the qualitative content analysis. This part elaborates the interview discussions. Researcher shows the responses in qualitative content analysis.

\section{Results and Discussion}

Three undergraduates consented to take an interest in the investigation and offer their lived encounters with me. Every member gave general foundation data like family structure, social, entrepreneurial background, and instructive foundation. The one-on-one meetings gave members a freedom to straightforwardly share their experiences, instructive encounters, their trainings and how they start their enterprising excursion. Name of respondents were replaced with as respondent 1, 2 and 3.

Respondent 1was 22 years old and student of B. Ed program, she was running a Coaching Academy. She was facing many financial problems as well as a lot of pressure from family to start earning. The reason behind to become an entrepreneur she replied:

"I want to become self-independent, self-independency is the power of women to don't rely on family, I don't want to do job as I won't be bound myself. My own venture was my dream, and I am very passionate about this."

When respondent was asked about the challenges, she has faced she said:

"Finding the rental place is very hard task for me because I am living in very small home and I don't have enough space for sitting arrangements for students, I have my saved income which I used to find a busy location for my business. The main problem which I have faced the Good will (an amount of money you have to pay the owner of shop or place you are hiring other than rent). The Rent mafia disturbed me a lot as they know I am a girl so they can easily pressurize me other than that regulations 
from government were the big challenge. It is a rule when you start business in commercial place, you have to register your business and pay taxes. As I am starting my business on very low scale and I don't know about the business registration process. So, I took help from women business chamber, they helped me about the process of returning tax files. The next problem, I have faced the marketing challenges, I used flyers and brochures for my business promotions."

She told about the importance of vocational trainings and the importance of skills "I know, skills are very necessary with the education, I have skills, so I have earned for myself and family."

When she was asked about the financing and importance of women empowerment,

"She said I have my own savings which I have utilized to get the rental place, she said the worst scenario was that when I took loan from my family member, she defines that through Entrepreneurship education and entrepreneurial mind set women can earn better and they will be empowered.

Respondent 2was running a home bakery business; she was the student of Food and Nutrition. She has two sisters and one brother. She makes cakes and cupcakes with fondant and her bakery items are very famous.

So, when she was asked about Entrepreneurial journey, she said

"My first customer was my father, for him I baked chocolate cookies and he paid delivery charges too. I am very passionate for doing something on my own, from my younger age I was very fond of doing something different".

When we discussed about challenges regarding financing and Entrepreneurial set up, she replied like this:

"My family especially my father supports me, I have saved my pocket money and I started learning and doing baking courses. I want to do something different, so I have started fondant baking, my friends and family supports me and gave me orders and from my home kitchen I have started my baking, I have faced lot of problems like availability of food item, baking products, edible color, Food gels, cake decorations, they were not available locally. So, I have to use the imported products which were very costly. Finding out the best ingredients was very hectic process as I am doing fondant baking. So, their products are very expensive and hard to find. I ordered from local online stores, but this cost me very expensive. I started contacting with direct suppliers from whole sell market and buy the stuff on whole selling price. When I started my business commercially, I have faced the advertisement problem, so I used the WhatsApp advertisement technique and through social media I did my business promotions". 
After getting experience in this field, her view point was as "I have started my gluten free baking products business too. I am doing my studies in Food and Nutrition, so I know about the nutritional benefits of every food product. I attracted my clients with my unique value proposition, and they attracted. I post my cakes and cupcakes pictures on my Instagram, Facebook and on WhatsApp status, so all my clients got updated. This is a rule in business out of sight out of mind, so I have to keep updated my customers".

She said there is a deep relationship between Entrepreneurial education and women Empowerment. If you are educated as well as skilled and you have passion, you can do everything of your choice. Skill development and training is the key to Empowerment, they are interrelated with each other. I am not dependent on my family.

Respondent 3 was running a traditional dresses boutique. She was doing her BS in computer sciences. Her mother used to stitch traditional dresses. She has four sisters and belongs to educated family. Her Entrepreneurial journey was not easy, but she worked very hard.

She said "Business is all about a new idea, innovation. My mother was switching clothe from my childhood. I saw her struggling day and night. As I am IT student and I learn from online courses of Entrepreneurship that in Business does not work hard work smart. So, I have decided to start a unique and different business. As my mother and my sisters are very creative, we have decided to make Traditional dresses. In markets traditional handmade dresses are very costly and their material was not good. They used cheap material and sell very expensive. The main problem we faced the middleman who bought the dresses from us in very less price and sell in market very costly. We cannot get the profit we want. So, we have decided to approach the market and customer directly. We had made our Facebook page and Instagram account, and uploaded our dress pictures. From word of mouth many customers approach us, as we are selling our products in economical prices as compared to market, people attracted. We skipped the middleman and get direct approach to shopkeepers. In many schools Pakistan cultural days are celebrated, we contacted with schools and gave them offer to buy our traditional dresses on economical price. This idea worked and we got a huge clientele".

The most important factor of successful business is family support, without support it's very difficult to succeed; you need domestic help especially from male member of family. Being a woman, the other gender took advantage of that"I want to be an Entrepreneur because I want my own power and fame. I want to be a boss not employee, so I worked very hard".

She said that Entrepreneurship must be the part of our curriculum and there will be the linkage between universities and industries, so students get internships, and they get skilled. Empowered women are creative, they have personnel knowledge and skills, they are well matured in their relationships as well as they are economic independent. So, in my views without skill training or entrepreneurship women have 
to face many hurdles, with the help of computer or smart phones you can learn everything you want, but you have to be determined and passionate.

The central matter found in this analysis that the understudies who are taught prepared and very much went with the most recent methodologies and strategies they are acquiring more. At the point when we examined about the financing of adventures generally said they took credits and spend their saving. As a matter of fact, in Pakistan there are numerous stages from where understudy get advances for their endeavors like Prime Minister's Youth Business Loan plan is offered by Government of Pakistan for little exchanges essentially for jobless instructed youth for foundation or broadening their business undertakings so they can be a piece of supporting business and diminishing joblessness and deprivation in Pakistan. Public Bank, Summit, Bank of Khyber, Bank of Punjab, and Telenor Microfinance bank are likewise giving advances. Numerous Government and Private Associations presented plans for understudies. At long last all members are supportive of Entrepreneurship Education and their connection with Economic Empowerment of females.

\section{Conclusion}

In interviews with students they offered their input in regards to business training and monetary strengthening of females and they accepted that Entrepreneurship schooling ought to be the piece of instructive projects during their studies at university level. After realizing the current situation and their concerns, it was discovered that girls need to act naturally autonomous, instead of asking from their families they need to accomplish something all alone. They need to acquire not for their selves but rather likewise for their families. They are energetic about their talents. They need their own forces and position just as popularity, which is the primary purpose for of being an Entrepreneur. On the off chance that we talked about that point the primary difficulties when they started their new pursuits the originally was pressure from family and social requirements.

In Pakistan females are dealing with numerous issues like financial, social, moral badgering from other gender and numerous yet they are still attempted to defeat with these difficulties. The issues being faced by entrepreneurs included financial issues, not getting family support, Transportation issues just as the advertising issues, they do not have the foggiest idea how to advance their business, utilizing of webbased media. Entrepreneurs are ignorant to think about for association with providers, they likewise do not think going to discover the wholesalers as opposed to purchasing from neighborhood shops.

\section{Recommendations}

1. Government need to give higher inclination to Entrepreneurship instruction through arrangement of new gear in organizations, hired proficient staff, 
with up to dated educational plan, variety of courses and monetary help for understudies.

2. Exceptional encouraging procedures or persuasive strategies ought to be utilized. Guardians and society mindfulness ought to be must from school level Entrepreneurship Awareness courses will be begun.

3. Entrepreneurship is recommended as a part of curriculum and a functional linkage between universities and industries may be strengthened through internships and skilled activities. 


\section{References}

Akhtar, S., Yousuf, M. I., \& Parveen, Q. (2021). Gender and age difference in attitude of secondary school students towards physical activities and barriers: A study from Pakistan. International Review of Social Sciences, 9(2), 1991-203.

Batliwala, S. (1994). Empowerment of Women in South Asia: Concepts and Practices, Asian-South Pacific Bureau of Adult Education and Freedom from Hunger Campaign, New Dehli.

Betancourt, T. S., Meyers-Ohki, S. E., Stevenson, A., Ingabire, C., Kanyanganzi, F., Munyana, M., \& Beardslee., W. R. (2011). Using mixed-methods research to adapt and evaluate a family strengthening intervention in Rwanda. African Journal of Traumatic Stress, 2, 32-45.

Gartner, W. B., \& Shane, S. A. (1995). Measuring entrepreneurship over time. Journal of Business Venturing, 10(4), 283-301.

Gopika,G., John, R.,\& Jose,E.(2015). Women Empowerment through Entrepreneurship and its Glitches:Atheoretical approach. International Journal of Scientific Research and Management, 3(4), 2677-2679.

Kumar, M., \& Kumar, S. (2015). Entrepreneurship Education: Concept, Characteristics and Implications for Teacher Education. Shaikshik Parisamvad (An International Journal of Education), 5 (1), 21-35.

Kuratko, D. (2005). The Emergence of Entrepreneurship Education: Development, Trends and Challenges. Entrepreneurship Theory and Practice, 29, 577-598.

Kuratko, D.F.,\& Hodgetts, R. M. (2013). Entrepreneurship:Theory,Process, Practice. Journal of Business and Management Sciences, 1, 119-127.

Mohsin, M., \& Syed, J. (2020). The missing doctors: An analysis of educated women and female domesticity in Pakistan. Gender, Work E Organization, 27(6), 1077-1102.

Muhib, Y., \& Khan, N. A. (2010). The prospects of entrepreneurial education in Pakistan: An economic perspective. Journal of Independent Studies and ResearchManagement, Social Sciences and Economics, 8(2), 1-10.

Nachimuthu, G. S., \& Gunatharan, B. (2012). Empowering women through entrepreneurship: A study in Tamil Nadu, India. International Journal of Trade, Economics and Finance, 3(2), 143-148.

Najeeb, F., Morales, M., \& LopezAcevedo, G. (2020). Analyzing female employment trends in South Asia. Bonn, Germany: IZA-Institute of Labor Economics. 
Naseer-Ud-Din, Khaleeq, A. R., \& Yousaf, M. I., Akhtar, S. H. (2010). Role of university education in understanding of social respect in women. International Journal of Academic Research, 2(6), 180-187.

Parsad, R.,\& Sahey, S. (2000). Models for Empowering Women in Sinha Kalpana. Empowermrment of Women in South Asia.

Ranjha, A.N., Yousuf, M. I., \& Sarwar, M. (2011). An empirical study of socio-political aspects of women councilors under Pakistan local government. International Journal of Academic Research, 3(1), 625-629.

Umme, R., Yousuf, M. I., \& Dahar, M. A. (2021). Integration of peace promoting contents of social studies with other subjects at elementary level. International Review of Social Sciences, 9(1), 472-482.

Ward, A., (2006). An Integrated model of Entrepreneurship and Intrapreneurship. [Online] www.york.ac.uk/enterprise/cetle/docs/papers/integrated model v1.pdf

Yousuf, M. I. \& Imran, M. (2018). Teachers and parents' perceptions about learning abilities and skills among children at Montessori classes. Journal of Elementary Education, 28(1):87-97. 